\title{
Foreland provenance of thick conglomerates in the early stages of Carpathian Foredeep development: the case of the Sloboda Conglomerate (Lower Miocene), western Ukraine
}

\author{
Nestor OSZCZYPKO, Alfred UCHMAN and Ihor BUBNIAK
}

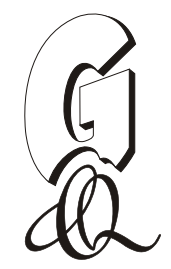

\begin{abstract}
Oszczypko N., Uchman A. and Bubniak I. (2012) - Foreland provenance of thick conglomerates in the early stage of Carpathian Foredeep development: the case of the Sloboda Conglomerate (Lower Miocene), western Ukraine. Geol Quart., 56 (4): 789-802, doi: $10.7306 / \mathrm{gq} .1055$

The upper part of the Lower Miocene Sloboda Conglomerate, a 250-1400 m thick unit, was deposited mainly on an alluvial fan and fan delta during the early stages of Carpathian Foredeep development. During of the Old Styrian overthrust movements of the Carpathian orogen, a forebulge was formed, which supplied clasts to the conglomerate. The clasts are dominated by Late Proterozoic-Early Cambrian phyllites, while Paleozoic carbonates are common, and Mesozoic and other rocks are rare. The source area formed mainly by a prolongation of the Małopolska Massif that was involved in the forebulge; this was located close to a palaeovalley cut into Mesozoic and Paleozoic rocks, buried under younger strata. Additional material was derived from the advancing front of the Carpathian Flysch nappes.
\end{abstract}

Nestor Oszczypko and Alfred Uchman, Institute of Geological Sciences, Jagiellonian University, Oleandry 2a, 30-063 Kraków, Poland, e-mails: nestor.oszczypko@uj.edu.pl, alfred.uchman@uj.edu.pl; Ihor Bubniak, Geological Faculty, Ivan Franko Lviv National University, Hrushevsky 4, 79005 Lviv, Ukraine, e-mail: ibubniak@yahoo.com (received: April 23, 2012; accepted: June 14, 2012; first published online: October 4, 2012).

Key words: molasse, forebulge, alluvial fan, fan delta, Boryslav-Pokuttya Nappe, Ukraine.

\section{INTRODUCTION}

During the transition from a remnant oceanic to a peripheral foreland basin, shallow-marine and continental molasse sediments accumulate, both on top of an accretionary wedge (piggyback basin) as well on top of a pre-existing foreland platform basement (foredeep basin, see Einsele, 2000). The majority of foreland basins of the Alpine-Carpathian orogens, i.e. the North Alpine Foreland Basin (Matter et al., 1980; Stockmal and Beamont, 1987) and the Carpathian Foredeep Basin (Picha et al., 2006; Oszczypko et al., 2006) are located on the West European Platform, and were supplied both from the orogen and foreland platform. The foreland-origin deposits usually include mudstones, siltstones, sandstones and carbonates; however, locally conglomerates are present (Fig. 1C), some of which are very thick. Their sedimentary environment and origin have been resolved to different degrees and the origin of some units remains poorly understood, despite long study. This is true of the Lower Miocene Sloboda
Conglomerate, a $250-1400 \mathrm{~m}$ thick unit that is known from surface exposures of the Boryslav-Pokuttya Nappe and the subsurface succession of the Sambir (Stebnyk) Nappe across a limited area of the Eastern Carpathians (Fig. 1). This paper describes and interprets of the upper part of the Sloboda Conglomerate (upper member sensu Fedushak, 1962) in the Boryslav-Pokuttya Nappe.

\section{PREVIOUS WORK}

The Sloboda Conglomerate was distinguished by Paul and Tietze (1877) as the "conglomerates from Runhury Sloboda". These conglomerates have been studied by many Polish and Ukrainian geologists working on the foreland of the Ukrainian Carpathians (Zuber, 1888, 1901, 1915; Teisseyre, 1927; Bujalski, 1930, 1934, 1938; Fedushak, 1962; Vialov, 1965; Chernov, 1984; and references therein). In the NW part of the Ukrainian Carpathians, the Truskavets Conglomerate is regarded as an equivalent of the Sloboda Conglomerate 


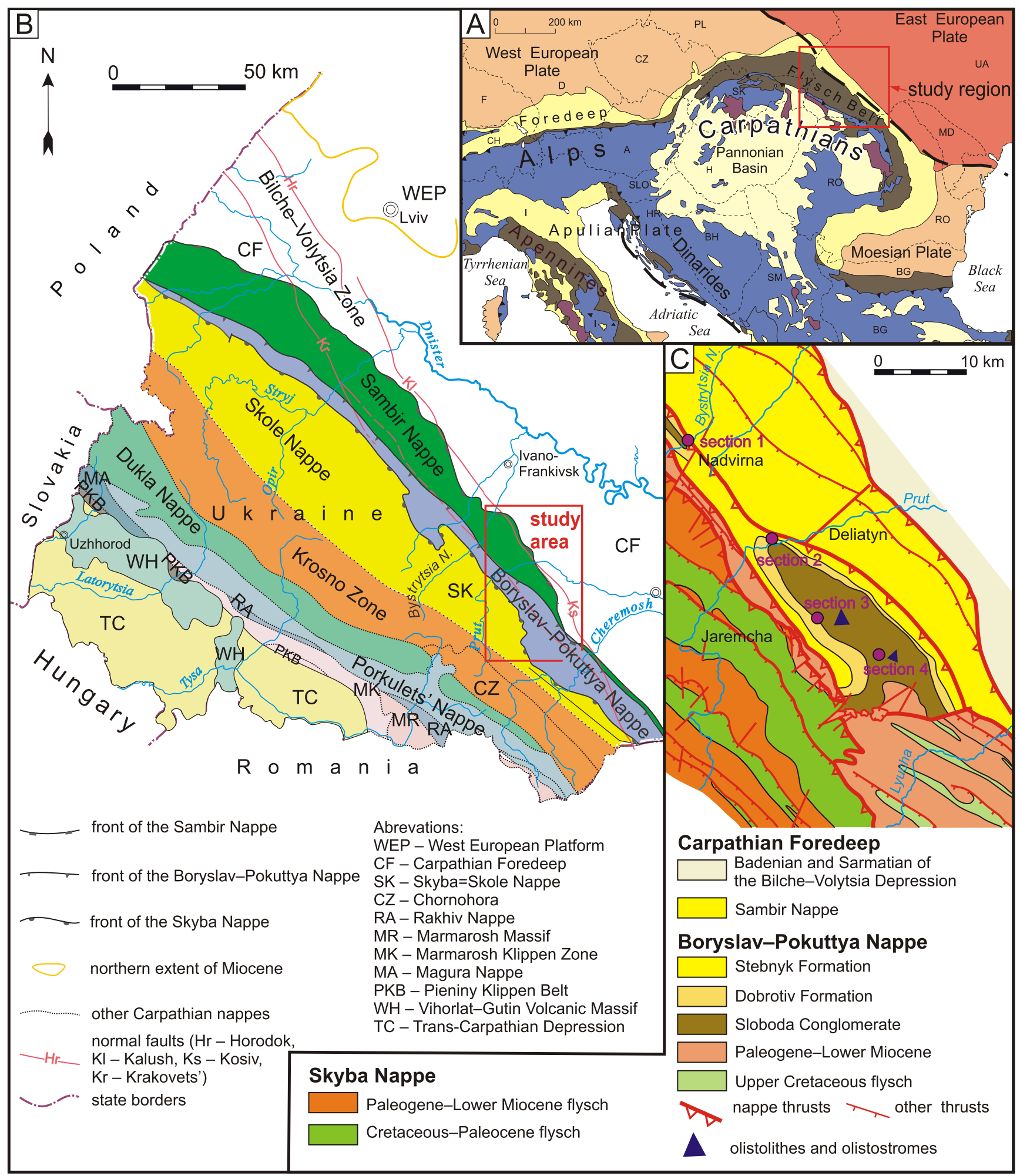

Fig. 1. Location maps

A - position of the study area in the Alpine-Carpathian system (after Picha, 1996, modified by Oszczypko et al., 2006); B - tectonic map of the Ukrainian Carpathians (after Ślączka et al., 2006, simplified); C - geological map of the Delatyn-Lanchyn area (compiled by Jankowski et al., 2007, supplemented) 
(Kropaczek, 1919). Its counterparts are also known from the Sub-Carpathian Unit in Romania as the Plesu, Pietricica and Biresti conglomerates (Micu, 1982).

The origin of the Sloboda and Truskavets conglomerates has been referred to an ancient Cenozoic ridge that was uplifted at the northern margin of the Carpathian Flysch basins (Szajnocha, 1883). The ridge was considered as a mountain ridge spreading along the basin margin from the Holy Cross Mts. in Central Poland to Dobrogea in eastern Romania (Zuber, 1901).

The most detailed descriptions of the conglomerates are given by Fedushak (1962) and Chernov (1984). The Sloboda Conglomerate has been subdivided into three members (Bujalski, 1930; Fedushak, 1962; see also Chernov, 1984): a lower member 15-20 m thick, locally exposed; a middle member widespread, 100-110 m thick, comprising, sandstones and clays (grey, dark grey clays and sandstones with lenses of salt and gypsum); and an upper member, comprising up to $250 \mathrm{~m}$ of coarse conglomerates with boulders.

\section{GEOLOGICAL SETTING}

In the Eastern Carpathians (Fig. 1A, B) both piggyback and foreland molasse (foredeep) basins are present. The former include the Early Miocene folded molasse deposits of the Boryslav-Pokuttya and Sambir (Stebnyk) nappes in the front of the Ukrainian Outer Carpathians (Oszczypko et al., 2006) and the Marginal Fold and Sub-Carpathian Unit in Romania. The foredeep basin is filled by the Middle-Late Miocene autochthonous molasse deposits developed on the East European Platform in the so-called Bilche-Volytsia Depression in Ukraine and the Focsani Depression in Romania (Micu, 1982).

\section{BORYSLAV-POKUTTYA NAPPE}

The Boryslav-Pokuttya Nappe forms the frontal overthrust of the Ukrainian Carpathians (Fig. 1B). This unit extends into Romania where it is known as the Marginal Fold Unit. The Boryslav-Pokuttya Nappe is up to $5 \mathrm{~km}$ across and is sandwiched between the Skiba (Skyba, Skole) and Sambir nappes. It is composed of flysch and molasse successions (see Andreyeva-Grigorovich et al., 1997, 2008; Koltun et al., 2005) and is subdivided (Fig.1B) into the Delatyn (higher, more internal) and the Runhury Sloboda (lower, more external) sub-nappes (Kulchytsky et al., 1997).

The Delatyn Sub-Nappe is composed of Cretaceous -Lower Miocene flysch analogous to that of the Skyba Nappe, which is overlain by the Early Miocene Polanytsia and Vorotyshcha formations (Fig. 2). The Polanytsia Formation, $700 \mathrm{~m}$ thick, is composed of grey argillites with intercalations of coarse-grained sandstone as well as clasts and blocks of halite and anhydrite; it passes upwards into the Vorotyshcha Formation (NN3-?NN4 Zone; see Andreyeva-Grigorovich et al., 2008). Locally, the upper part of the Vorotyshcha Formation is replaced by the Sloboda Conglomerate. The Runhury Sloboda Sub-Nappe is composed of the Sloboda Conglomerate and the

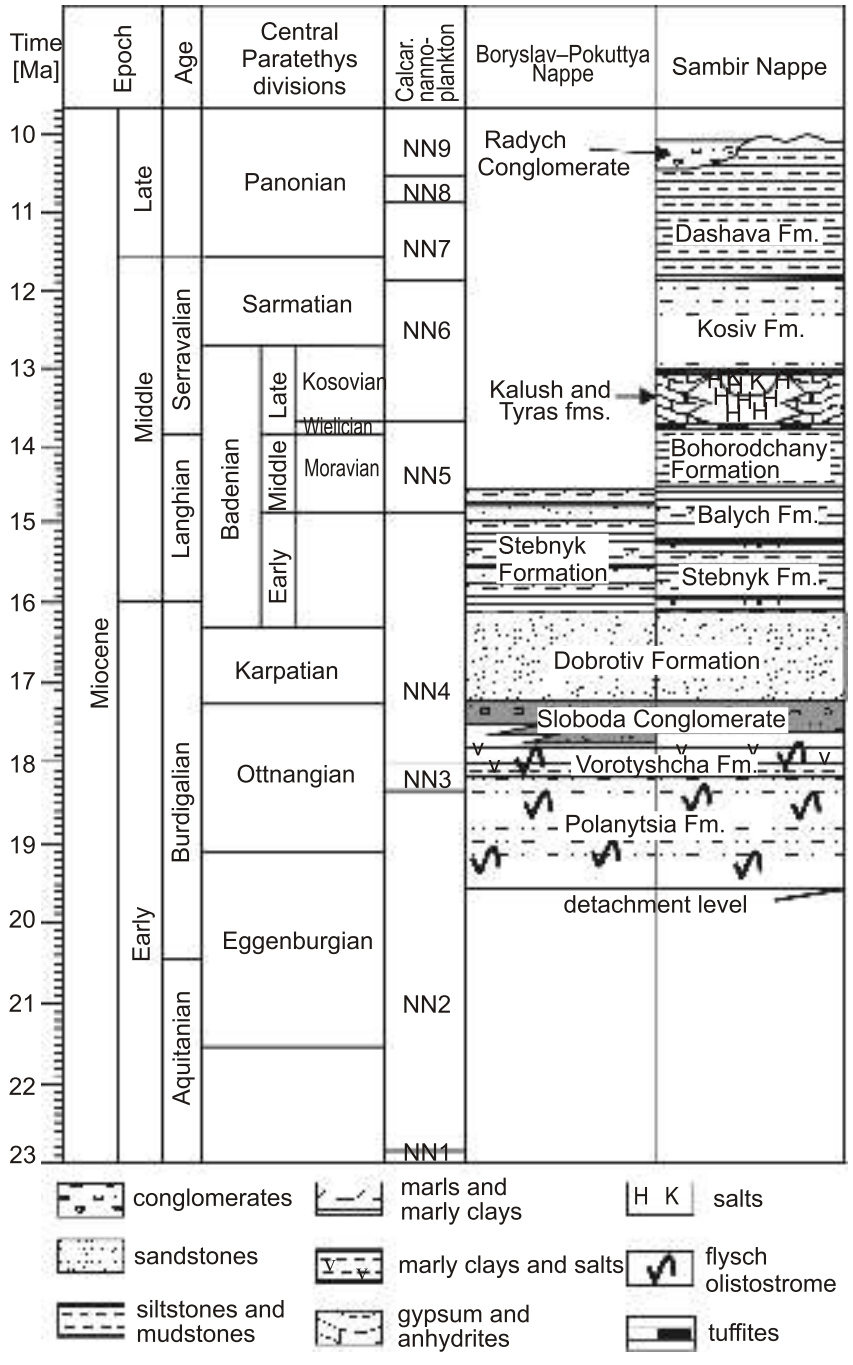

Fig. 2. Lithostratigraphic scheme of the Boryslav-Pokuttyaan and Sambir (Stebnik) nappes (after Oszczypko et al., 2006, supplemented)

Dobrotiv and Stebnyk formations. Boreholes show that the Sloboda Conglomerate is underlain by the Vorotyshcha Formation. According to published borehole data, the conglomerates are $450-500 \mathrm{~m}$ thick in the Starunia and Nadvirna areas, and 900-1400 m thick in the Runhury Sloboda area, respectively. Further to the SE, their thickness decreases to 100-250 m. Other thickness, based on detailed measurements in six sections located between the Bystrytsia Solotvynska valley (NW) and the Luchka Stream (SE) have been provided by Fedushak (1962, fig. 4). According to this author, the conglomerates are about $20 \mathrm{~m}$ thick in the Bystrytsia Solotvynska section, up to $300 \mathrm{~m}$ thick in the Bystrytsia Nadvirnanska and Oslava sections, and up to $380-450 \mathrm{~m}$ in the Runhury Sloboda, Nyzhny Bereziv and Luchka sections. The Sloboda Conglomerate passes upwards into the Ottnangian Dobrotiv Formation, which is up to $700 \mathrm{~m}$ thick (Andreyeva-Grigorovich et al., 1997, 2008). The Dobrotiv Formation is followed by variegated marls and sandstones of the Stebnyk Formation. 
The Dobrotiv and Stebnyk formations are famous for their tetrapod footprints (birds, gazelles, Hippidae) and rain drop marks in the Delatyn section (Vialov, 1966).

\section{SAMBIR NAPPE}

The Sambir Nappe (Fig. 1B, C), known in Romania as the Sub-Carpathian Unit, and in Poland as the Stebnik Nappe, is composed of folded Lower-Middle Miocene strata that are overthrust onto Sarmatian and Badenian deposits of the Bilche-Volytsia Zone of the Carpathian Foredeep (Oszczypko et al., 2006). The Sambir Nappe, up to $24 \mathrm{~km}$ wide (Fig. 1B), occupies a large tectonic depression at the front of the Boryslav-Pokuttya Nappe and is arranged in several thrust sheets. The lithostratigraphy of the basal part of the Sambir Nappe is still a matter of debate. Most authors (see Andreyeva-Grigorovich et al., 2008 and references therein) regard the Vorotyshcha Formation as the oldest unit, as indicated by borehole evidence (e.g., Gvizd 1 near of Nadvirna, and Uroz 6 NE of Boryslav), where the Vorotyshcha Formation was penetrated beneath the Sloboda Conglomerate and the Dobrotiv Formation, respectively (Koltun et al., 2005). Here, the Sloboda Conglomerate is up to $1000 \mathrm{~m}$ thick. Upwards, it passes into brackish or fresh-water sandstones and mudstones of the ?Ottnangian Dobrotiv Formation, which is up to $700 \mathrm{~m}$ thick (Andreyeva-Grigorovich et al., 1997, 2008). This formation is followed by variegated marls and sandstones of the Stebnyk Formation (Late Karpatian and Early Langhian; NN4 and NN5 zones; Andreyeva-Grigorovich et al., 1997, 2008). The Stebnyk Formation (Fig. 2) passes up into greenish and grey clays, mudstones and poorly cemented sandstones of the Balych Formation, regarded by Bujalski (1930) as the northern facies of the upper part of the Stebnyk Formation (see also Vialov, 1965).

In the Kalush area, the Stebnyk and Balych formations are undivided and pass upwards into the Bohorodchany Formation (100-250 m thick), which is composed of grey marly clays and sandstones containing a rich assemblage of Badenian planktonic foraminifera and calcareous nannoplankton of the NN5 Zone (Andreyeva-Grigorovich and Kulchytsky, 1985; Andreyeva-Grigorovich et al., 2003). In the southern sector of the Kalush area, the Bohorodchany Formation (Fig. 2) passes up into the evaporitic salt deposits of the Kalush Formation, or gypsum and salts of the Tyras Formation, belonging to the NN5 and NN6 zones, respectively (Andreyeva-Grigorovich et al., 2003). The youngest deposits, belonging to the Kosiv (Upper Badenian) and Dashawa (Sarmatian) formations, occur near Dobromil close to the Polish-Ukrainian border (Vashchenko and Hnylko, 2003). This series of deposits is terminated by the Radych Conglomerate. These deposits belong to the NN6-NN 9 zones (Andreyeva-Grigorovich et al., 2008).

\section{SECTIONS STUDIED}

Outcrops of the Sloboda Conglomerate begin in the Bystrytsia Solotvynska Valley near the villages of Dzvinyach and Starunia, and then in the Nadvirna area. The conglomerate also builds the core of the Runhury Sloboda Anticline, which is
3-4 km across. They are also known from the Pokuttya-Bukovyna Carpathians in the area SE of the Prut River, over a distance of about $20 \mathrm{~km}$.

The following sections of the Sloboda Conglomerate in the Boryslav-Pokuttya Nappe have been studied (Fig. 1C):

- section 1: cliffs along the left bank of the Bystrytsia Nadvirnanska River at Nadvirna (GPS co-ordinates: N48 32'17.4”; E2441'0.7'). These very long exposures represent the middle and upper part of the Sloboda Conglomerate and its transition to the Dobrotiv Formation (Fig. 3);

- section 2: a tributary gorge to the Oslava Stream to the Prut River at Dobrotiv (GPS co-ordinates: N48 32'21.0”, E2441'11.6”'). This section displays a transition of the uppermost part of the Sloboda conglomerates to the Dobrotiv Formation (Fig. 3);

- sections 3 and 4: exposures along the Oslava Stream at village of Oslava (section 3, GPS co-ordinates: N48 30'04.2"; E2442'34.0”'), which include a transition to the Dobrotiv Formation, and a $20 \mathrm{~m}$ high cliff at Sloboda (section 4: GPS co-ordinates: N48 30'14.6”; E244' 18.0'), which is built of fine conglomerate with outsized blocks of Devonian dolomites.

\section{LITHOLOGY OF CLASTS}

According to Fedushak (1962), the lower member of the Sloboda Conglomerate, 15-20 m thick, which crops out in the Luchka valley at Luchka, contains eight layers composed of pebble and gravel conglomerates and boulder conglomerates at the base of the member. Their clasts are composed mainly of fragments of metamorphic green schist, the content of which increases upwards from $20 \%$ at the base to $40 \%$. Moreover, quartzite $(3-15 \%)$ and limestone $(7-16 \%)$ clasts are present with a maximum in the middle part of this member. Other clasts are composed of dolomite (1.5-3\%; only at the base), black phyllite (4-18\%; with a maximum content in the lower part of the member), sandstone (5-11\%), clastic rocks from the Carpathian Flysch (34\% in the lower part and up to $25 \%$ in the upper part of the member; Fedushak, 1962, table 2).

Conglomerates of the upper member (200-250 m thick) consist of alternations of boulder-pebble and gravel layers passing upwards into sandstones, with 14 rhythmic units distinguished, each of them composed of 3, 5 or 7 layers (Fedushak, 1962, table 2). The lower part of this member consists of the coarsest and less sorted material with clasts ranging from $1 \mathrm{~mm}$ to $5 \mathrm{~m}$, where boulders and pebbles prevail. The composition of clasts in this member is more diverse than in the lower one. They are built of metamorphic green schist (10-90\%), quartzite (0-6\%), limestone (0-35\%), dolomite (0-40\%), grey and black phyllite $(0-80 \%)$, red phyllite $(0-15 \%)$, sandstone $(0-18 \%)$ and Carpathian flysch and other rocks (17\%) (Fedushak, 1962).

A brief survey of the lithology of the clasts in the exposures studied indicates that they are dominated by greenish, rarely reddish anchimetamorphic schists, the parent rocks of which are mostly mudstones and siltstones, some with fine-grained sandstone intercalations. They are most similar to the Upper Proterozoic-?Lower Cambrian rocks of this type from the 

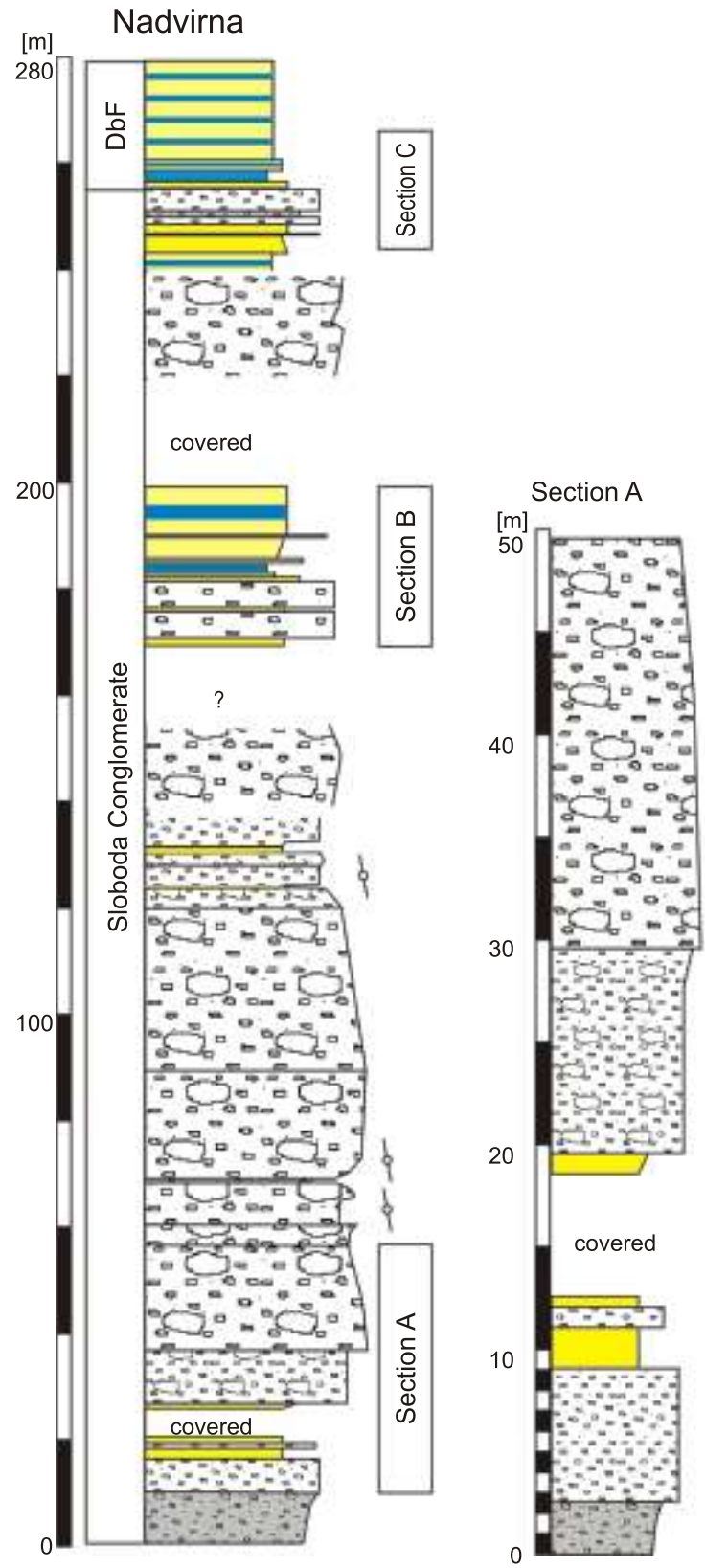
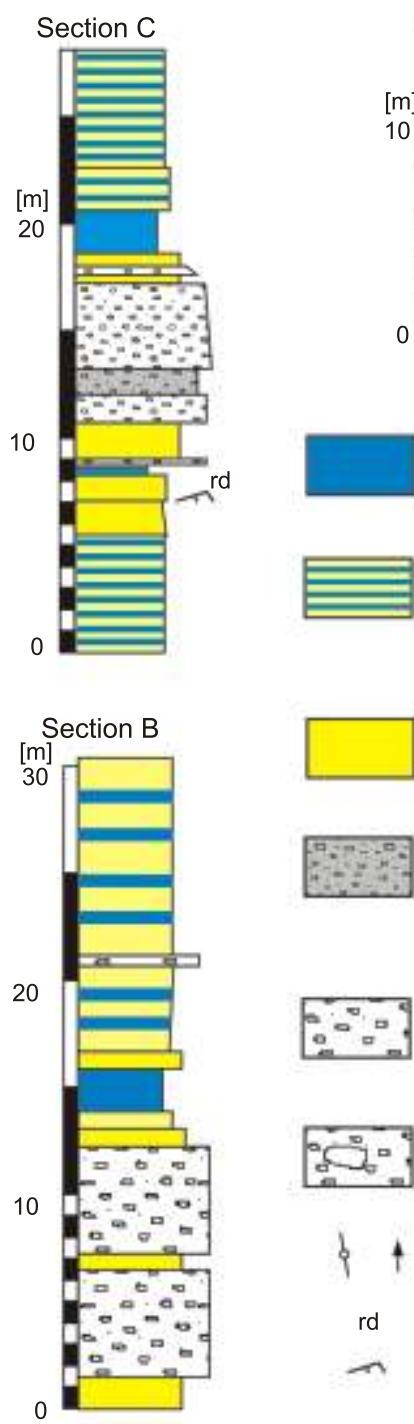

sandstone
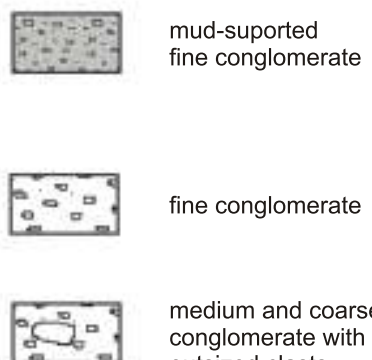

medium and coarse

conglomerate with

outsized clasts

i direction of clast orientation

rd

rain-drop imprints

$\rightarrow$

rippled lamination

Fig. 3. Studied sections of the upper part of the Sloboda Conglomerate in the Nadvirna and Zarichye sections

$\mathrm{DbF}$ - Dobrotiv Formation

Małopolska Massif in SE Poland (Po aryski, 1977) and from Dobrogea in Romania (Micu, 1982).

There are frequent clasts of whitish, partly recrystallized limestone, some of which are dolomitised, and/or contain echinoderm fragments, and of sandy limestone commonly with glauconite grains (Fig. 4D, E). More rare are sandy limestones, dolomitic in some clasts (Fig. 4G) that contain clasts of micritic limestone, fragments of siliceous rocks, metamorphic rocks with biotite, glauconite, quartz, ooids, sponge spiculesor echinoderm fragments. They are very similar to the Lower Paleozoic limestones (Silurian, ?Devonian) of the Podolia Carpathian foreland. Rare clasts of red quartzites probably derive from the same provenance (Old Red Sand- stone?). Strongly compacted quartz sandstones (Fig. 4F) are also Paleozoic in age.

The age of other, rare clasts is less obvious, especially those composed of light micritic limestone, fine-grained clayey-calcareous sandstone of quartz, mica, zircon and tourmaline, and intercalated with mudstone. Some micritic or fine calcarenitic limestone clasts, some sandy, rarely contain crushed tests of planktonic foraminifers (Fig. 4A) and possible Mesozoic calcareous dinoflagellates (Fig. 4B, C). A striking feature is the absence of Carpathian flysch lithologies (though these have been reported by Fedushak, 1962). 

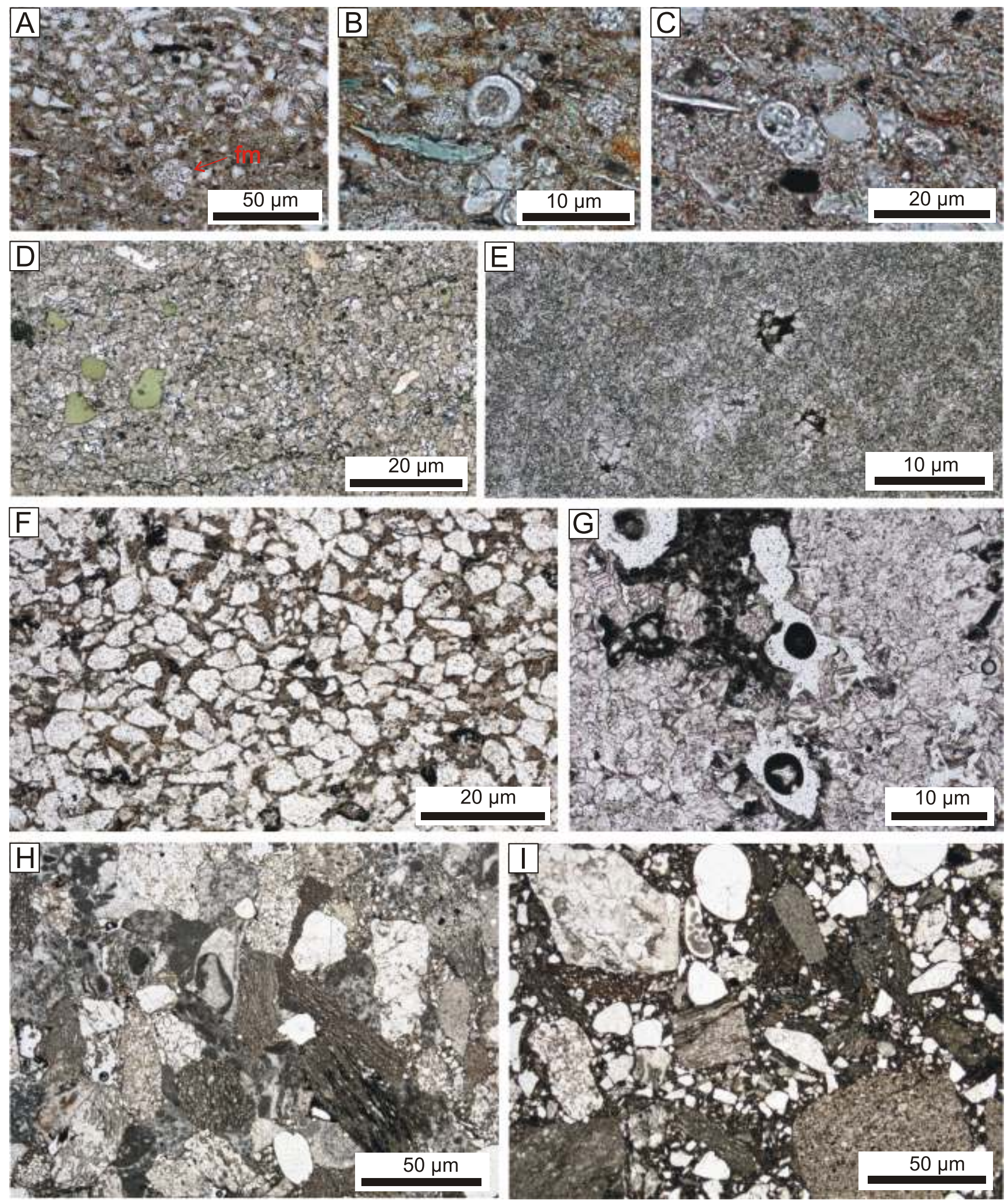

Fig. 4. Lithology of clasts and matrix in the Sloboda Conglomerate

A-C - micritic limestone with laminae of quartz sand with mica, chlorite, glauconite and bioclasts of planktonic foraminifers (fm in A) and calcareous dinoflagellates (B, C), Jurassic or Cretaceous (Sz/wp 801a); D - calcarenite with grains of glauconite, quartz and siliceous rock, Lower Paleozoic (Nadw 510); $\mathbf{E}$ - recrystallized micritic limestone with fragments of echinoderm, Lower Paleozoic (Sz/wp67a); F - fine-grained quartz sandstone with muscovite, biotite, fragments of siliceous rock, siliceous or locally siliceous-clayey cement, ?Lower Paleozoic (Sz/wp840/8); G - recrystallized dolomitic limestone with ?crinoids and unidentified bioclasts (Sz/wp840/6); H - matrix composed of very coarse sand-sized grains of bioclastic limestone (?Lower Paleozoic), metamorphosed mudstone and claystone (Upper Proterozoic-?Lower Cambrian), quartzite (?Lower Paleozoic) and quartz; calcareous and calcareous clayey cement (Sz/wp816); I - matrix composed of very coarse sand-sized grains of calcarenite, glauconitic sandstone, quartz, metamorphosed mudstone and phyllite, granitoid and gneiss; calcareous and calcareous clayey cement (Sz/wp831) 


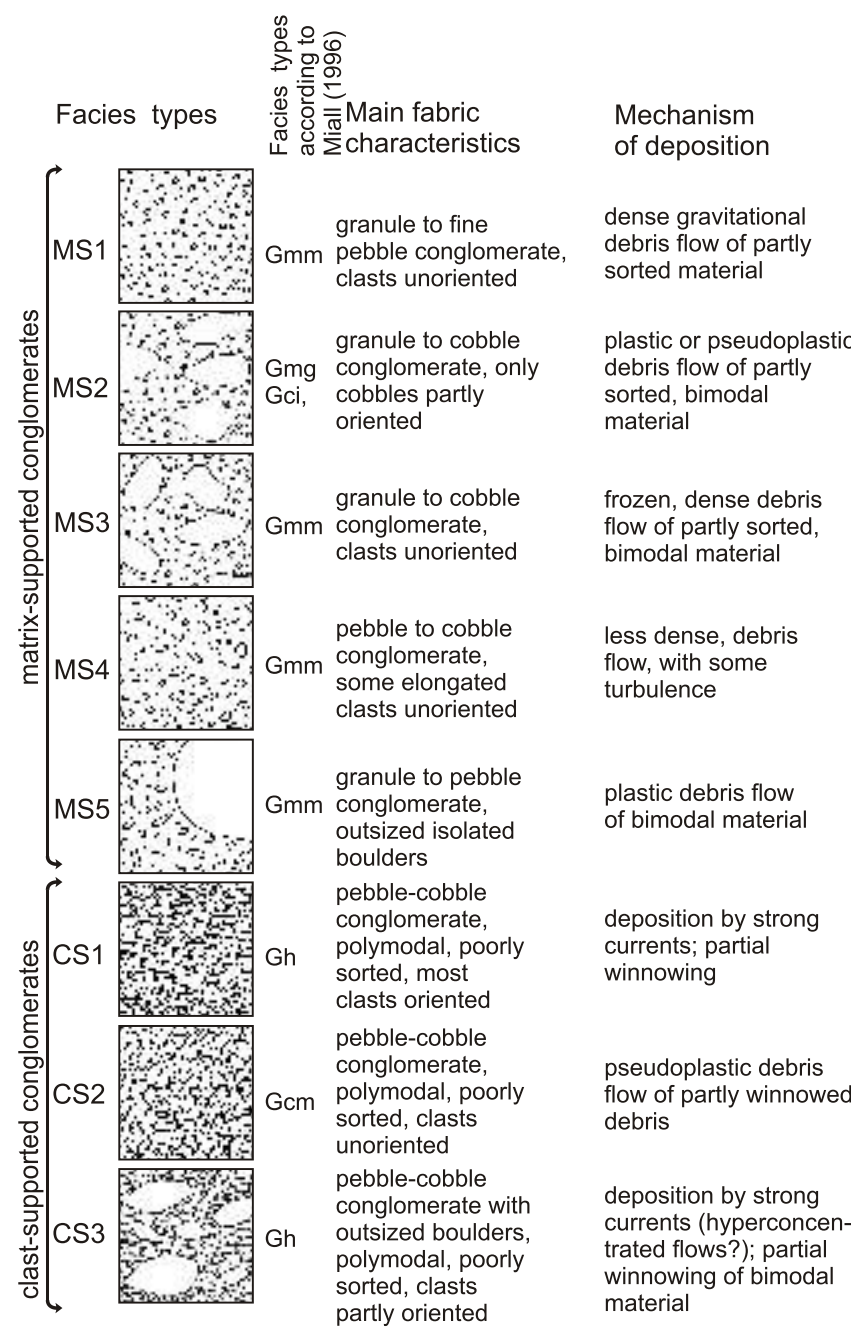

Fig. 5. Textural facies types of the conglomerates studied and interpretation of their mechanism of deposition

\section{TEXTURAL AND STRUCTURAL FEATURES OF THE CONGLOMERATES}

The conglomerates show five matrix-supported textural types (types MS1-MS5) and three clast-supported textural types (types CS1-CS3; Figs. 5 and 6). The former can be ascribed mainly to the facies Gmm of Miall (1996), except for the facies MS2, which can be ascribed either to facies Gmg or Gci. The clast-supported conglomerates belong to facies $\mathrm{Gh}$ or $\mathrm{Gcm}$ of Miall (1996). The grain size of clasts ranges from granules to coarse boulders or even to blocks, which reach about $5 \mathrm{~m}$ across. The clasts are mostly subangular and subrounded, rarely angular or rounded. The clasts of metamorphic rocks are mostly elongated. Their shape is controlled by the parting surfaces of the rock. The white dolomite clasts are more equidimensional and more rounded.

The clasts are unoriented (Fig. 6A, C) or oriented (Fig. 6B, $\mathrm{E})$ in the matrix-supported and clast-supported conglomerates.
Some of the oriented clasts display indistinct imbrication (Fig. 6E). In some layers, the conglomerates contain oversized boulders built foremost of Devonian limestone (Fig. 6D), the longer axes of which are oriented (Fig. 6F) except for in facies MS3, in which boulders are unoriented. The clasts are mostly polymodal, but in some beds poor sorting can be observed.

The conglomerates are generally grey, except for a few layers that are red (Fig. 7B). The matrix is composed mostly of poorly sorted coarse and very coarse sand-sized, mostly angular and subangular grains (Fig. 4H, I) with a transition to fine-grained conglomerate. The grains are of metamorphosed mudstone and claystone, phyllite (Upper Proterozoic-?Lower Cambrian), bioclastic calcarenite (?Lower Paleozoic), glauconitic sandstone, quartzite (?Lower Paleozoic), quartz, and locally of granitoid and gneiss. The cement is calcareous and calcareous clayey. In some matrix-supported fine conglomerates, the matrix is dominated by finer sand, silt and mud.

The conglomerates are mostly massive. In some parts they are organized in layers (Fig. 7A) composed of different textural types, usually with gradation between them. Commonly, coarsening up trends can be observed in packages that are $0.8-1.5 \mathrm{~m}$ thick. Rarely, conglomerates are arranged in beds (Fig. 7B), which are $0.5-1 \mathrm{~m}$ thick and separated by weakly expressed, non-erosive discontinuities. The layers and beds are tabular on the scale of the exposure, i.e. over a distance of $10-20 \mathrm{~m}$ in the largest exposures.

\section{SANDSTONE, SILTSTONE AND MUDSTONE INTERCALATIONS}

Sandstone intercalations are rare in the lower part of the section studied (section A of the Nadvirna section; Fig. 3). The sandstones are $0.2-2 \mathrm{~m}$ thick, poorly sorted, from fine- to very coarse-grained, massive or rarely parallel laminated, usually with a transition to conglomeratic sandstone and to fine-grained conglomerate (Fig. 8B).

In the upper part of the Sloboda Conglomerate (sections B and $\mathrm{C}$ of the Nadvirna section; Fig. 3), the sandstone intercalations are more common and the first intercalations of mudstone occur. The sandstones here are grey, poorly sorted, from fineto coarse-grained, but up section their sorting is better and grain-size decreases. They are massive or display parallel or ripple lamination, being more and more similar to the sandstones of the overlying Dobrotiv Formation.

In the transition to the Dobrotiv Formation at Zarichye (Figs. 3 and 4), medium beds are present. They are built of fine conglomerate in the lower part that passes into poorly sorted, coarse- to medium-grained sandstone in the upper part (Fig. 8C). They display cross-lamination, as well as lenses of fine conglomerate between the sand beds (Fig. 8D). Most of the sandstone beds are tabular on the scale of the exposure, however, one bed display a wedge-slaped cross section (Fig. 8A).

The intercalated siltstones and mudstones are grey and commonly parallel laminated, as in the Dobrotiv Formation. In one horizon, poorly preserved rain-prints have been observed. 

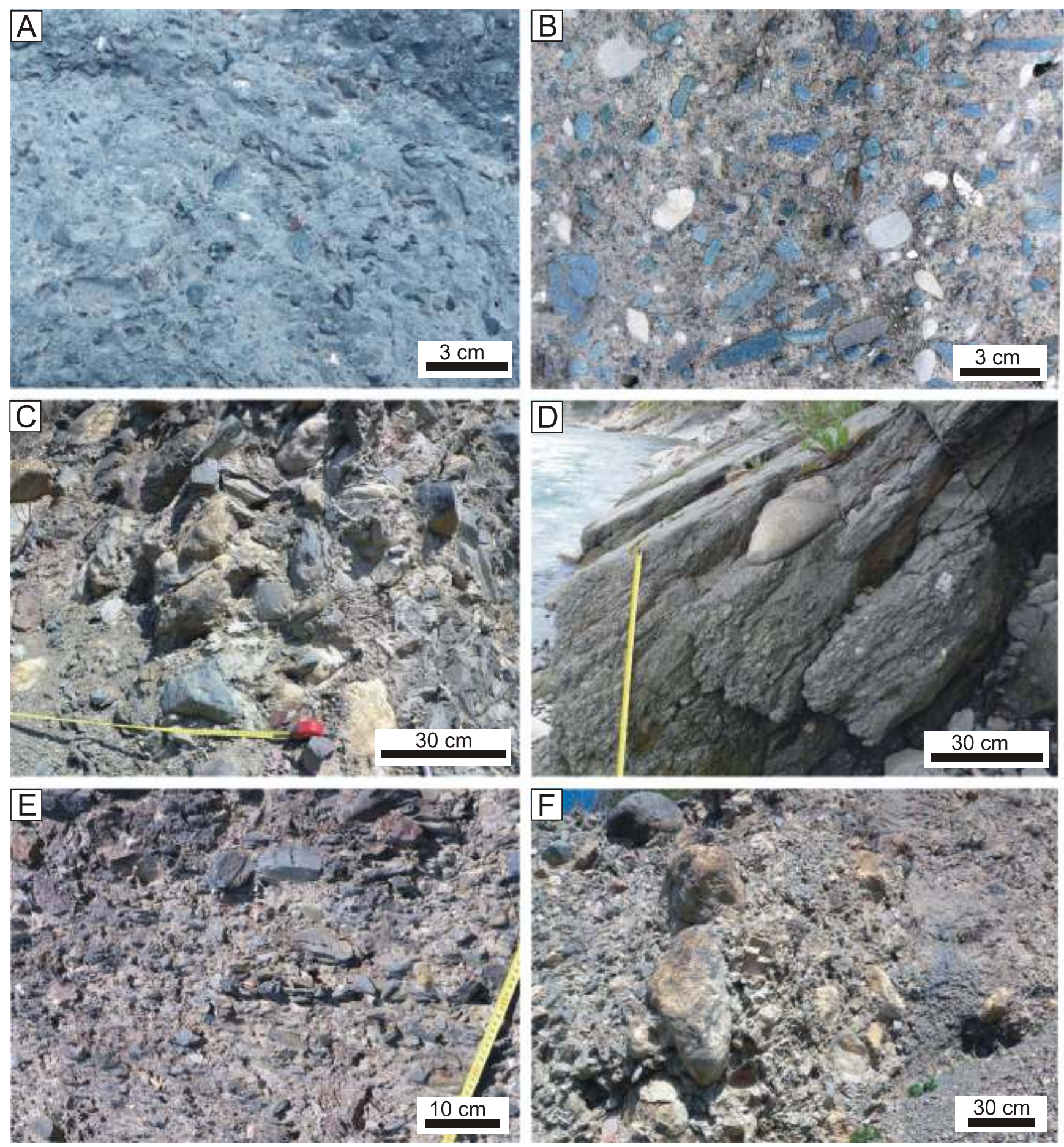

Fig. 6. Different types of conglomerates studied in the Nadvirna (A, C, E-F) and Zarichye (B, D) sections

A - matrix-supported granule-pebble conglomerate with unoriented clasts (facies MS1); B - matrix-supported granule-pebble conglomerate with some elongated oriented clasts (facies MS4); C - clast-supported pebble-cobble conglomerate without oriented clasts (facies CS2); D - matrix-supported granule-pebble conglomerate with oversized boulders (facies MS5); $\mathbf{E}$ - clast-supported pebble-cobble conglomerate with oriented clasts (facies CS1); $\mathbf{F}$ - to the left and middle, alternations of clast-supported pebble-cobble conglomerate with outsized boulders (clasts are partly oriented; facies CS3) and clast-supported pebble-cobble conglomerate without oriented clasts (facies CS2), on the right, matrix-supported granule-pebble conglomerate with unoriented clasts (facies MS1) 

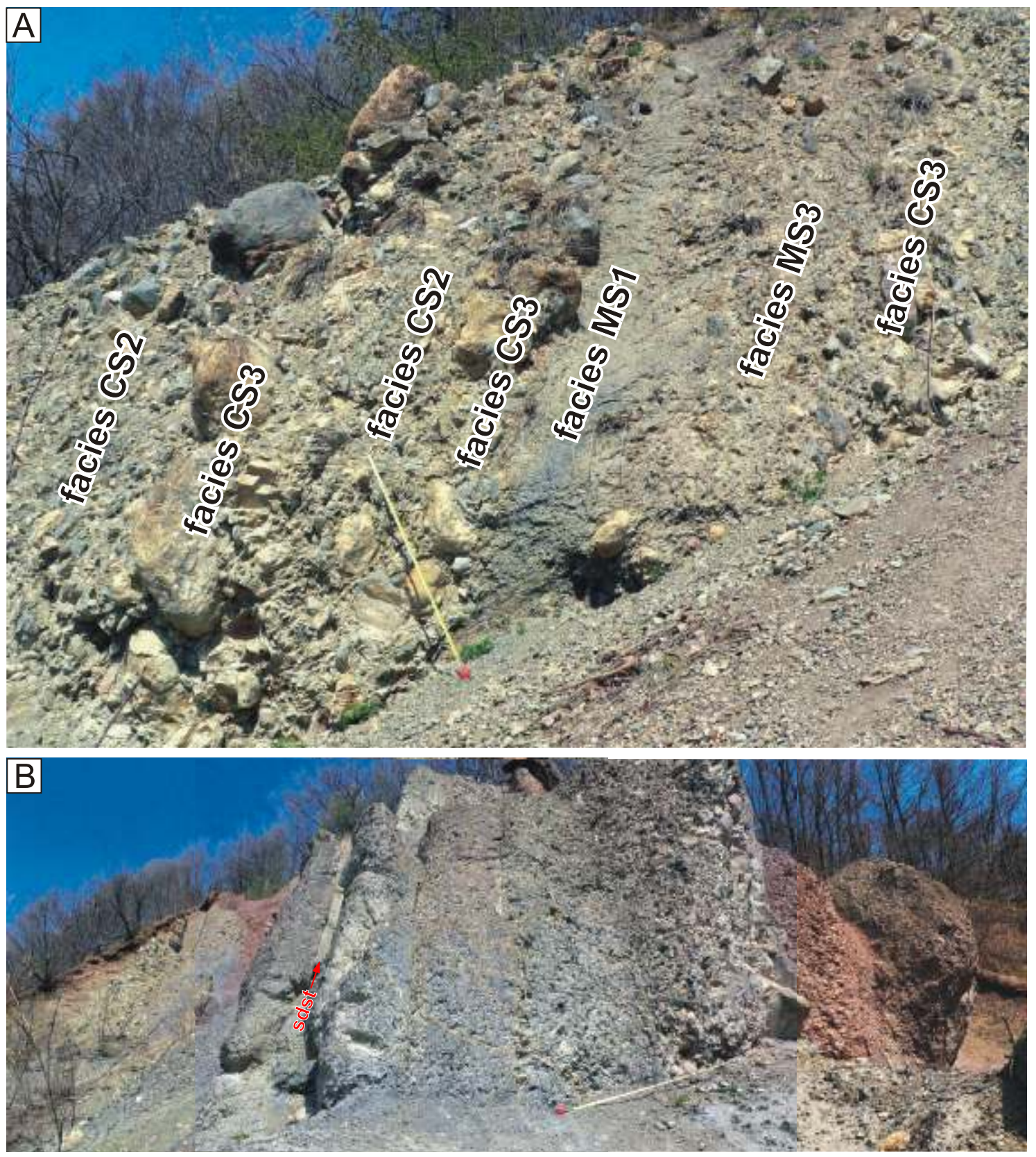

Fig. 7. Different facies of the alluvial fan conglomerates in the Nadvirna section

A - alternation of facies. Note gradational transitions between them and mostly coarsening up trends; B - poorly expressed bedding in grey and red conglomerates. Sandstone intercalation (sdst) to the left. Note coarsening up trend in the middle-right part of the photograph

\section{PALAEOENVIRONMENT}

The larger part of the conglomerates, especially in the lower part of the section (Fig. 3), has been deposited by debris flows of unsorted or partly sorted material. This refers particularly to the matrix-supported, poorly sorted conglomerates (Shultz, 1984; DeCells et al., 1991). Sedimentation of debris flows and of crudely bedded conglomerates with inverse grading is possible in subaquaeous conditions (Nemec, 1990b) but better organization of beds and more sandy and muddy intercalations, in part cross-bedded, would be ex- pected in such a case (e.g., Postma, 1984). The low maturity and roundness of the clasts suggests deposition close to the source area. This is typical of the proximal and middle parts of alluvial fans (e.g., Miall, 1996), where debris flows cover a large part of the fan. Inverse grading and concentration of outsized clasts in the upper part of beds is interpreted as movement out of basal shear zone within the flow (Hubert and Filipov, 1989; Wagreich and Strauss, 2005).

Facies CS1 and CS3 have been deposited by strong flows (e.g., Jo et al., 1997), probably by hyperconcentrated (see Benvenuti, 2003) caused by heavy rain. However, massive, 

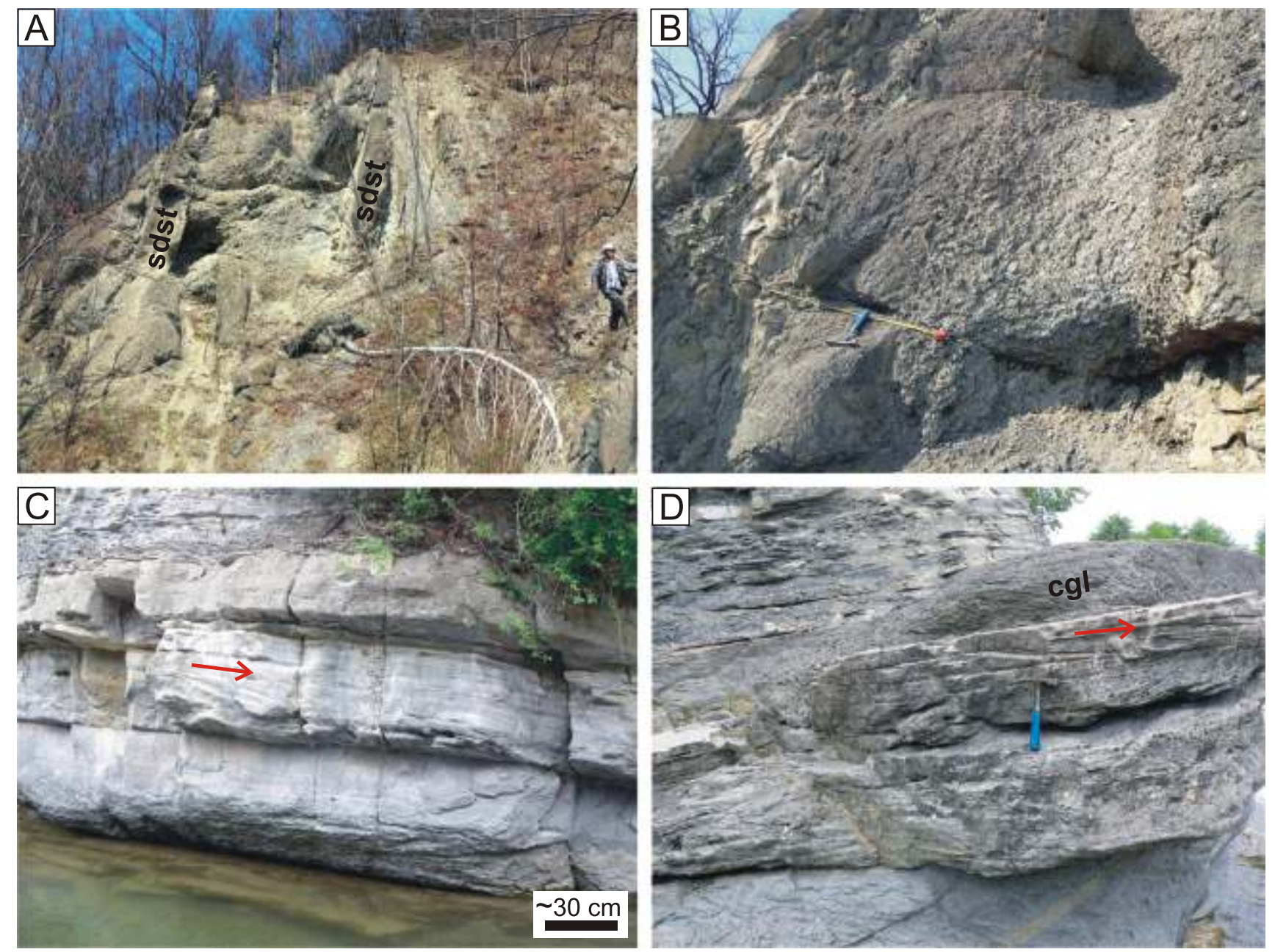

Fig. 8. Different facies of fan delta deposits in the Nadvirna (A, B) and the Zarichye (C, D) sections in the Oslava River gorge (section 2)

A - conglomerates alternating with sandstone beds; the sandstone bed from the right is wedge-shaped; $\mathbf{B}$ - sandstones (to the left) covered by conglomerates of fluctuating clast size and matrix content; $\mathbf{C}$ - conglomerate-sandstone beds, mudstones in the upper part; the middle sandstone bed is cross-bedded; inclination of laminae points to transport to the north-east (red arrow); $\mathbf{D}$ - cross-bedded sandstones, siltstones and mudstones and a lens of fine-grained conglomerate (cgl); inclination of laminae points to transport to the north-east (red arrow); in A and B, bedding subvertical, top from the right

poorly sorted, clast-supported, cobble-boulder conglomerates can also be interpreted as debris flows (DeCells et al., 1991), including pebble-cobble conglomerates which are inversely-to-normal and inversely graded, with larger clasts "floating" at the tops of beds (Rohais et al., 2008). Such a mechanism can explain the general absence of scouring and channelling. However, this feature can also be explained by deposition as gravel sheets from sheet floods or as flat bars in shallow channels rather than in channel trenches. The dominant tabular geometry is commonly referred to sheet floods (Benvenuti, 2003). Accumulation of poorly sorted, disorganized conglomerates is possible by aggradation on longitudinal bars during floods (Hwang et al., 1995). Also, massive to crudely stratified gravel deposits are ascribed to deposition in braided streams by migration of longitudinal bars (Chwang and Chough, 1990).

Partial sorting may be caused by the sieve effect or by winnowing of finer grains by infiltrating waters. Deposition of better sorted conglomerates can take place as bars and gravel sheets. In some levels, the boulders are axially oriented relative to smaller clasts. This excludes orientation of rolling boulders (Benvenuti, 2003) caused by traction. Thus, the blocks have been transported in a larger mass of smaller clasts.

The upper part of the section, where sandstone and mudstone intercalations are present (Fig. 3), displays features of a fan delta, which can be ascribed to the gently sloping, "mouth bar-type" lacking cross-sets (Nemec, 1990a) or to the Hjulström-type with a shoal-water profile, supplied from an alluvial cone; the latter is characterized by "unconfined, ephemeral streams involving mass flows" and formed "along basin-margin fault scarps and fjord margins" (Postma, 1990). Large foresets typical of Gilbert-type fan deltas (e.g., Rohais et al., 2008) are absent. This fits the conglomerates being overlain by sandstones and mudstones of the Dobrotiv Formation, the shallow water origin of which is indicated by several horizons of emersion with raindrop imprints, desiccation cracks and tetrapod footprints (Vialov, 1966). A fan delta environment has been postulated for two segments of the Nadvirna section (sections B and C; Fig. 3), which are about 15 and $10 \mathrm{~m}$ thick, respectively. The conglomerates present in these segments dis- 
play features of debris flow deposits. The sandstones, which display parallel or ripple laminations, were deposited by upper and lower flow regime currents. Rain-prints suggest an exposed mud plain. Cross-bedded conglomerate-sandstone beds (Fig. 8C) are evidence of unidirectional migration of a bar, in which sediments are sorted. Such sediments are referred to as floor bar deposits (Benvenuti, 2003). Deposition of laminated mudstone beds was possible under cover of water.

The thickness of the section segments interpreted as fan delta deposits is thin in comparison to the total thickness of the conglomerate and limited to its top part. Therefore, the main body of the upper unit sensu Fedushak (1962) can be interpreted as an alluvial fan, irrespective of the controversal distinction between a subaerial fan delta and an alluvial fan (Postma, 1990; Benvenuti, 2003). The alluvial fan of the Sloboda Conglomerate falls into the category of piedmont fans (Shukla, 2009) formed commonly in foredeep basins. The large thickness in comparison to the size of the lithosome and the absence of erosional incisions (at least on the scale of exposures) point to an aggradational mode of deposition, which is usually controlled by strong subsidence (García-García et al., 2006). This corresponds well to the early stage of subsidence in the Carpathian Foredeep caused by nappe loading (Kováč et al., 1998; Oszczypko, 1998; Oszczypko et al., 2006).

\section{DISCUSSION}

The Early to Late Miocene Ukrainian Carpathian Foredeep Basin developed during transformation of a residual flysch basin into a peripheral foreland basin related to the advancing Carpathian front (see Oszczypko et al., 2006; and references therein). The final flysch deposition (Polanytsia Formation) took place in the late Early Burdigalian (Ottnangian) in the northernmost part of the Outer Carpathian basins (represented by the Boryslav-Pokuttya Nappe in Ukraine, and the Marginal Folds unit in Romania). Transition to the evaporitic Vorotyshcha Formation in Ukraine (Andreyeva-Grigorovich et al., 1997, 2008) and the Salt Formation in Romania (Micu, 1982) records a change to molasse sedimentation that took place probably both on the Carpathian accretionary wedge as well as on the platform basement. The Vorotyshcha Formation contains both blocks of Jurassic-Early Cretaceous platform-derived limestone and flysch-derived olistoliths (see Andreyeva-Grigorovich et al., 2008; Olszewska et al., 2011). SE of the Prut Valley, in the Luchka, Nyzhny Bereziv and Runhury Sloboda sections, the lower part of the Sloboda Conglomerate interfingers with the Vorotyshcha Formation, while NW of the Bystrytsia Solotvynska River, the Sloboda Conglomerate as well as the overlying Dobrotiv Formation are fully replaced by the upper part of the Vorotyshcha Formation (Fedushak, 1962, fig. 4). This further indicates the synorogenic nature of this formation.

The Early Miocene evaporitic sedimentation was followed (Fig. 2) by the Intra Burdigalian (Old Styrian) phase of compression, when the Outer Carpathian basins were folded and uplifted. This was accompanied by outward overthrusting and formation of the subsiding flexural foreland (foredeep) basin at the moving orogenic front, and partly as the piggy back basins on top of the orogenic wedge (see Kováč et al., 1996, 1998).

The latter mainly refer to the Boryslav-Pokuttya-Sambir Basin. The flexural downwrapping of the foreland platform resulted in formation of a forebulge elevation, which supplied coarse clastic sediment to the alluvial fan and fandelta of the Sloboda Conglomerate.

Clasts of the Sloboda Conglomerate are dominated by Precambrian-Lower Cambrian, green, black, and red phyllites, followed by Paleozoic, mainly Devonian dolomites and limestones, and to the lesser extent by Jurassic-Lower Cretaceous limestones. The Sloboda Conglomerate contains also flysch-derived, mainly Oligocene, olistoliths and olistoplaques. Such a composition of the clasts suggests an additional supply from the Carpathian orogenic wedge. The same provenance of clasts characterizes the Truskavets Conglomerate, which is distributed along the NW margin of the Ukrainian Carpathians, $80 \mathrm{~km}$ away from the nearest outcrops of the Sloboda Conglomerate (Chernov, 1984). While the derivation of the Truskavets Conglomerate from the SE prolongation of the Małopolska Massif (Fig. 9) is no doubt, the source area for the Sloboda Conglomerate remains problematic, mainly because the present-day geographic position of the Proterozoic phyllites exposed during the Early Miocene is less well-known in proximity to that conglomerate (Fig. 9). However, Buła and Habryn (2011) suggested prolongation of the Małopolska Massif to the area south of Ivano-Frankivs'k. In our opinion, the forebulge with the core made of Proterozoic-Lower Cambrian phyllites of the Małopolska Massif (its prolongation towards South Dobrogea in Romania; Micu, 1982) as well as Paleozoic shales and carbonates, could have been located at last 30-40 km NW from present-day position of the Sloboda Conglomerate (Fig. 9).

Taking into account the present day width of the Boryslav-Pokuttya and Sambir nappes, the width of the Boryslav-Sambir Basin may be estimated at least $50 \mathrm{~km}$. In this situation, the Early Burdigalian ( 20 Myr) front of the Outer Carpathians would has been located at least $90 \mathrm{~km} \mathrm{SW}$ from the present-day position of the front of the Ukrainian Flysch Carpathians (Fig. 9). The Boryslav-Pokuttya-Sambir Basin were supplied mainly with clasts derived from the uplifted forebulge and occasionally by slumps and gravity flows from the orogenic front. The southwards palaeotransport in the Nadvirna section has been documented by measurements of imbrication.

A potential source area of the Mesozoic and older carbonate clasts may be associated with a zone devoid of Mesozoic rocks that has been identified by boreholes SE of the Bystrytsia Nadvirnanska River. In this area, both in the Carpathian front as well as beneath the Carpathians, a deep, up to $30 \mathrm{~km}$ wide palaeovalley was discovered by means of boreholes and seismic surveys. Toward the east, the valley separates into two tributaries, one to the right (Korshiv-Ispas) and one to the left extending south towards Kolomya (see Popadyuk in Oszczypko et al., 2006). This palaeovalley runs to the south and was eroded during the Paleogene-Early Miocene. Probably, the depositional system was fed from the prolongation of the Małopolska Massif adjacent to the palaeovalley in the north-west. The lower part of the Sloboda Conglomerate was also supplied from the Carpathian Flysch front. 


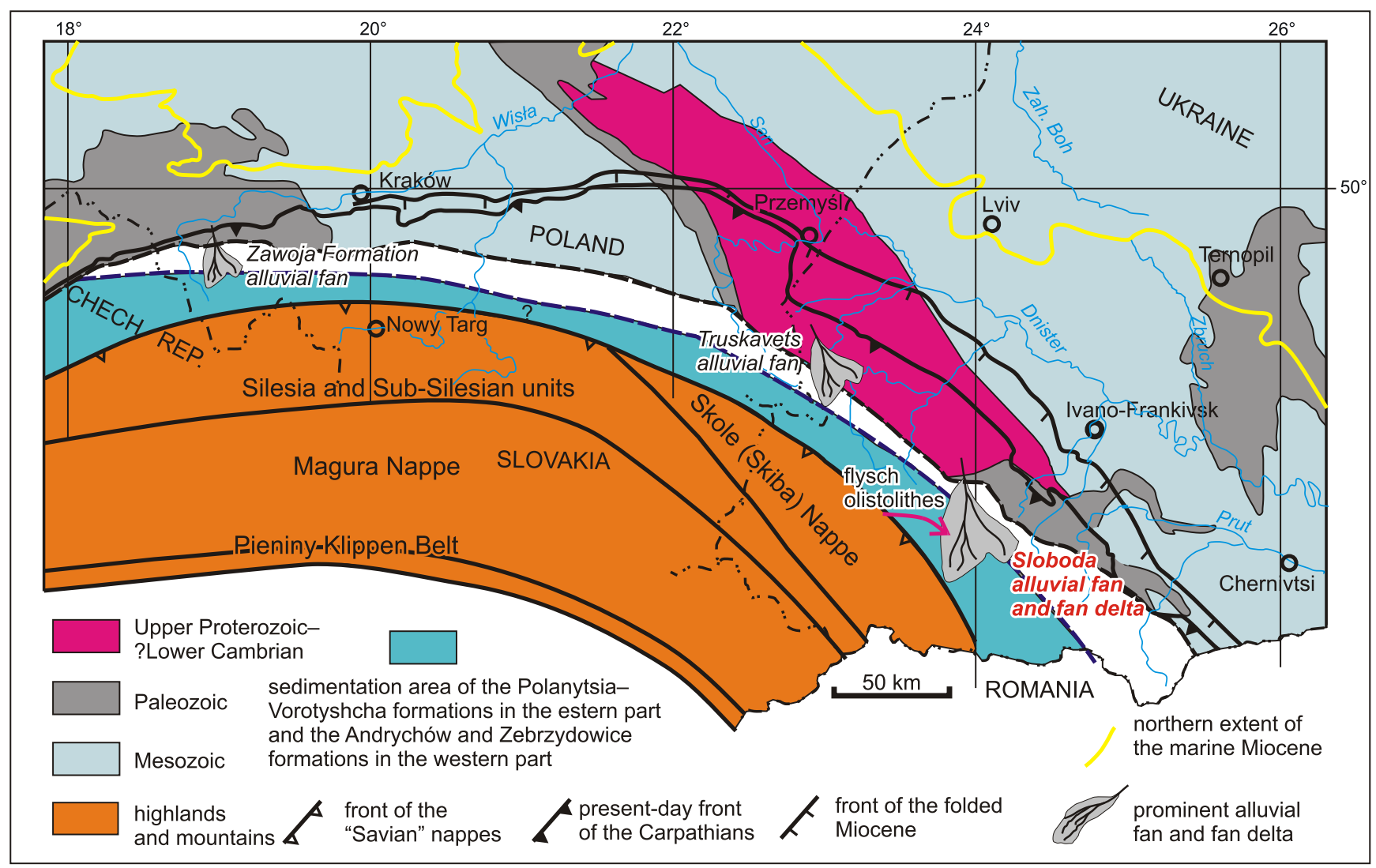

Fig. 9. Late Ottnangian palinspastic palaeogeography of the foreland of the Polish and Ukrainian Carpathian Foredeep (based on Oszczypko and Oszczypko-Clowes, 2003; Oszczypko et al., 2006; Buła and Habryn, 2011, supplemented)

\section{CONCLUSIONS}

1. Early to Middle Miocene deposits (Polanytsia Formation, Vorotyshcha Formation) in the Boryslav-Pokuttya Nappe record syntectonic transformation of the residual flysch basin into the Carpathian Foredeep Basin.

2. The overlying Sloboda Conglomerate was deposited mainly on an alluvial fan (with a high contribution of high-density gravity flows) followed by a fan delta.

3. Clasts of the Sloboda Conglomerate were derived from the platform forebulge that was formed as a consequence of the Old Styrian thrust movements. The material was transported from the source area located in a proximity to a palaeovalley running SE of Bystrytsia Nadvirnanska now beneath Miocene cover.

4. The source area may be structurally a prolongation of the Małopolska Massif involved in the forebulge.

Acknowledgments. N. Oszczypko and A. Uchman have been supported by the Jagiellonian University (DS funds). D. Salata (Kraków) helped in petrographic determinations of the clasts. D. Reháková (Bratislava) provided her opinion on some microfossils. This paper benefitted from useful reviews by M. Kovač (Bratislava) and Y. Koltun (Lviv). T. Peryt (Warszawa) provided further editorial comments.

\section{REFERENCES}

ANDREYEVA-GRIGOROVICH A.S. and KULCHYTSKY A.Y. (1985)The age of evaporatic sequence of the Kalush-Golyn field. In: Evaporites of Ukraine: 176-181(in Russian). Naukova Dumka, Kiev. ANDREYEVA-GRIGOROVICH A., KULCHYTSKY Y.O., GRUZMAN A.D., SMIRNOV S.E., TROFIMOVICH N.A., SAVITSKAYA N.A., SHVAREVA N.J., LOZYNYAK P.Y., PETRASHKEVICH M.I., PORTNYAGINA L.O. and IVANIN A.V. (1997) - Regional strati- graphic scheme of Neogene formations of the Central Paratethys in the Ukraine. Geol. Carpath., 48: 123-136.

ANDREYEVA-GRIGOROVICH A.S., OSZCZYPKO N., ŚLĄCZKA A., SAVITSKAYA N. and TROFIMOVICH N. (2003) - Correlation of Late Badenian salt of the Wieliczka, Bochnia and Kalush areas (Polish and Ukrainian Carpathian Foredeep). Ann. Soc. Geol. Pol., 73: 67-89. 
ANDREYEVA-GRIGOROVICH A.S., OSZCZYPKO N., ŚLĄCZKA A., OSZCZYPKO-CLOWES M., SAVITSKAYA N.A and TROFIMOVICZ N. (2008) - New data on the stratigraphy of the folded Miocene Zone at the front of the Ukrainian Outer Carpathians. Acta Geol. Pol., 58: 325-353.

BENVENUTI M. (2003) - Facies analysis and tectonic significance of lacustrine fan-deltaic successions in the Pliocene-Pleistocene Mugello Basin, Central Italy. Sedim. Geol., 157: 197-234.

BUJALSKI B. (1930) - Budowa geologiczna przedgórza Karpat Wschodnich między Łukwią a Rybnicą. Spraw. Państw. Inst. Geol., 6 (2): 235-268

BUJALSKI B. (1934) - Profil doliny Prutu między Worochta a Dobrotowem. In: Przewodnik wycieczki: 5-9. Pol. Tow. Geol., Lwów.

BUJALSKI B. (1938) - Arkusz 3, Nadwórna. Ogólna Mapa Geologiczna Polski w skali 1:100. Wojskowy Instytut Geograficzny, Warszawa.

BUŁA Z. and HABRYN R. (2011) - Precambrian and Paleozoic basement of the Carpathian Foredeep and the adjacent Outer Carpathians (SE Poland and western Ukraine). Ann. Soc. Geol. Pol., 81: 221-239.

CHWANG I.G. and CHOUGH S.K. (1990) - The Miocene Chinbuk Formation, southeastern Korea: marine Gilbert-type fan-delta system. IAS Spec. Publ., 10: 235-254.

CHERNOV V.G. (1984) - Psephites of the Soviet Carpathians. Moscow University Press, Moscow.

DeCELLS P.G., GRAY M.B., RIDGWAY K.D., COLE L.B., PIVNIK D.A., PEQUERA N. and SRIVASTAVA P. (1991) - Controls on synorogenic alluvial-fan architecture, Beartooth Conglomerate (Palaeocene), Wyoming and Montana. Sedimentology, 38: 567-590.

EINSELE G. (2000) - Sedimentary Basins. Evolution, Facies and Sediment Budget, 2nd edition. Springer, Berlin.

FEDUSHAK M.J. (1962) - Origin of the exotic conglomerates of the Vorotyshcha succession of the Ukrainian Fore-Carpathians (in Ukrainian). Publisher of the Ukrainian Academy of Sciences, Kiev.

GARCÍA-GARCÍA F., FERNÁNDEZ J., VISERA S.C. and SORIA J.M (2006) - Architecture and sedimentary facies evolution in a delta stack controlled by fault growth (Betic Cordillera, southern Spain, late Tortonian). Sedim. Geol., 185: 79-92.

HUBERT J.F. and FILIPOV A.J. (1989) - Debris-flow deposits on alluvial fans on the western bank of the White Mountains, Owens Valley, California, U.S.A. Sedim. Geol., 61: 177-205.

HWANG I.G., CHOUGH, S.K., HONG S.W. and CHOE M.Y. (1995) Controls and evolution of fan delta systems in the Miocene Pohang Basin, SE Korea. Sedim. Geol., 98: 147-179.

JANKOWSKI L., KOPCIOWSKI R. and RYŁKO W., eds. (2007) - Geological Map of the Outer Carpathians: borderlands of Ukraine and Romania 1: 200 000. Pol. Geol. Inst., Warsaw.

JO H.R., RHEE C.W. and CHOUGH S.K. (1997) - Distinctive characteristics of a stream flow-dominated alluvial fan deposit: Sanghori area, Kyongsang Basin (Early Cretaceous), southern Korea. Sedim. Geol., 110: $51-79$.

KOLTUN Y., DUDOK I., KOTARBA M., ADAMENKO O., PAVLYUK M., BURZEWSKI W. and STELMACH O. (2005) - Geological setting and petroleum occurrence of the Starunia area, fore-Carpathian region, Ukraine. In: Polish and Ukrainian Geological Studies (2004-2005) at Starunia Area of Discoveries of Woolly Rhinoceroses (ed. M. Kotarba): 61-77. Pol. Geol. Inst., Warsaw.

KOVAČ M., HUDACKOVA N., RUDINEC R. and LANKREIJER A. (1996) - Basin evolution in the foreland and hinterland of the Carpathian accretionary prism during the Neogene: evidence from the Western to Eastern Carpathians Junction. Ann. Tecton., 10: 3-19.

KOVAČ M., NAGYMAROSY A., OSZCZYPKO N., ŚLACZKA A., CSONTOS L., MARUNTEANU M., MATENCO L. and MARTON E. (1998) - Palinspastic reconstruction of the Carpathian-Pannonian region during the Miocene. In: Geodynamic Development of the Western Carpathians (ed. M. Rakus): 189-217. Slovak Geol. Surv., Bratislava.

KROPACZEK B. (1919) - Borysław. Studium geologiczne. Według materiałów zebranych przez śp. Kropaczka zestawił J. Grzybowski, tekst i atlas. Kraków.
KULCHYTSKY A.Y., LOZYNIAK P. and PETRASKEVYCH M. (1997) - Basic problems of geological structure and investigation of mineral resources in the Carpathian Region (in Ukrainian with English summary). Mem. Shevchenko Sc. Soc., 1: 25-45.

MATTER A., HOMEWOOD P., CARON P., RIGASSI D., van STUIJVENBERG J., WEIDMANN M. and WINKLER W. (1980) Flysch and molasse of western and central Switzerland. In: Geology of Switzerland, a Guide Book (ed. R. Trümphy), part B: 261-293. Schweiz Geol. Kommission, Wepf, Basel.

MIALL A.D. (1996) - The geology of fluvial deposits; sedimentary facies, basin analysis and petroleum geology. Springer, Heidelberg.

MICU M. (1982) - Explanatory notes to lithotectonic profiles of Miocene molasses from Central Moldovia (Eastern Carpathians, Romania). Veröff. Zentralinst. Phys. Erde AdW DDR, 66: 117-136.

NEMEC W. (1990a) - Deltas - remarks on terminology and classification. IAS Spec. Publ., 10: 3-12.

NEMEC W. (1990b) - Aspects of sediment movement on steep delta slopes. IAS Spec. Publ., 10: 29-73.

OLSZEWSKA B., PAUL Z., RYŁKO W. and GARECKA M. (2011) Biostratygrafia olistolitów wapiennych zewnętrznego pasa skałkowego Karpat i skał otaczających. ALM studio-Paul Hupper, Kraków.

OSZCZYPKO N. (1998) - The Western Carpathian foredeep - development of the foreland basin in front of the accretionary wedge and its burial history (Poland). Geol. Carpath., 49 (6): 415-431.

OSZCZYPKO N. and OSZCZYPKO-CLOWES M. (2003) - The Aquitanian marine deposits in the basement of Polish Western Carpathians and its paleogeographical and paleotectonic implications. Acta Geol. Pol., 53: 101-122.

OSZCZYPKO, N., KRZYWIEC P., POPADYUK I. and PERYT T. (2006) - Carpathian foredeep basin (Poland and Ukraine): its sedimentary, structural, and geodynamic evolution. AAPG Mem., 84: 261-318.

PAUL K. and TIETZE E. (1877) - Studien in der Sandsteinzone der Karpathen. Jb. Geol. Reichsanst., 27: 1-72.

PICHA F. (1996) - Exploring for hydrocarbons under thrust belts - a challenging new frontier in the Carpathians and elsewhere. AAPG Bull., 80 (10): 1547-1564.

PICHA F., STRANIK Z. and KREJČI O. (2006) - Geology and hydrocarbon resources of the Outer Western Carpathian and their foreland, Czech Republik. AAPG Mem., 84: 49-175.

POSTMA G. (1984) - Slumps and their deposits in fan delta front and slope. Geology, 12: 27-30.

POSTMA G. (1990) - Depositional architecture and facies of river and fan deltas: a synthesis. IAS Spec. Publ., 10: 13-27.

PO ARYSKI W. (1977) - The Baikalian orogen in southern Poland. In: Geology of Poland, 4, Tectonics (ed. W. Po aryski): 84-98. Wyd. Geol., Warszawa.

ROHAIS S., ESCHARD R. and GUILLOCHEAU F. (2008) - Depositional model and stratigraphic architecture of rift climax Gilbert-type fan deltas (Gulf of Corinth, Greece). Sedim. Geol., 210: 132-145.

SHUKLA U.K. (2009) - Sedimentation model of gravel-dominated alluvial piedmont fan, Ganga Plain, India. Internat. J. Earth Sc. (Geol. Rd.), 98: 443-459.

SHULTZ A.W. (1984) - Subaerial debris flow deposition in the Upper Paleozoic Cutler Formation, western Colorado. J. Sedim. Petrol., 54: 759-772.

ŚLĄCZKA A., KRUGLOV S., GOLONKA J., OSZCZYPKO N. and POPADYUK I. (2006) - Geology and hydrocarbon resources of the Outer Carpathians, Poland, Slovakia, and Ukraine: general geology. AAPG Mem., 84: 221-258.

STOCKMAL G.S. and BEAMONT C. (1987) - Geodynamic models of convergent margin tectonics: Canadian Cordillera and the Swiss Alps. Can. Soc. Petrol. Geol. Mem., 12: 393-411.

SZAJNOCHA W. (1883) - Badania geologiczne. Przew. Naukowo-Literacki, 11: 187-191.

TEISSEYRE H. (1927) - Der geologische Bau des Flyschrandes zwischen Nadwórna und Delatyn (in Polish with German summary). Kosmos, 30: $1-18$. 
VASHCHENKO V.O. and HNYLKO O.M. (2003) - Pro stratygrafiyu ta sedymentologichni osoblyvosti neogenovykh molas Boryslavs'koPokuts'kogo pokryviv Ukrains'kogo Prykarpattya. Geologia i Geokhimia Horyuchykh Kopalyn, (1): 87-101.

VIALOV O.S. (1965) - Stratigraphy of Neogene Molasse of the Carpathian Foredeep (in Russian). Naukova Dumka, Kiev.

VIALOV O.S. (1966) - Trace-fossils and their paleontological value (in Russian). Naukova Dumka, Kiev.
WAGREICH M. and STRAUSS P.E. (2005) - Source area and tectonic control on alluvial-fan development in the Miocene Fohnsdorf intramontane basin, Austria. Geol. Soc., Spec. Publ., 251: 207-216.

ZUBER R. (1888) - Atlas geologiczny Galicji, zeszyt 2. Komisya Fizjograficzna Akad. Um., Kraków.

ZUBER R. (1901) - O pochodzeniu fliszu. Kosmos, 26: 232-243.

ZUBER R. (1915) - Zarys budowy północno-wschodnich Karpat. Rozprawy i wiadomości z Muzeum im. Dzieduszyckich, 1: 191-210. Lwów. 